\title{
PENGGUNAAN BERBAGAIJENIS FILTER UNTUK PEMELIHARAAN IKAN HIAS AIR TAWAR DI AKUARIUM
}

\author{
Bambang Priono ${ }^{* *}$ dan Darti Satyani* ${ }^{* *}$ \\ $\left.{ }^{*}\right)$ Pusat Penelitian dan Pengembangan Perikanan Budidaya \\ Jl. Ragunan 20, Pasar M inggu, Jakarta Selatan 12540 \\ E-mail: bpriono21@yahoo.com \\ *) Balai Penelitian dan Pengembangan Budidaya Ikan Hias \\ Jl. Perikanan No. 13, Pancoran Mas, Depok 16346
}

\begin{abstract}
ABSTRAK
Akuarium merupakan salah satu wadah untuk pemeliharaan ikan hias baik tawar maupun laut, betapapun indahnya ikan hias apabila tidak ditunjang dengan penampilan, aksesoris, dan dekorasi yang memadai, maka nilai keindahan akan berkurang. Penggunaan filter untuk mendukung salah satu sintasan ikan hias sangat penting. Terdapat banyak jenis-jenis filter yang dapat digunakan di dalam akuarium, dengan bentuk, desain, ukuran, dan harga yang bermacam-macam pula. Namun demikian, fungsi utama filter sebernarnya adalah untuk (1) menghilangkan atau mengangkat kotoran atau sisa kotoran dari air, (2) mengangkat atau menghilangkan bahan kimia dari air yang membuat air menjadi berwarna (warna coklat)/keruh atau bahan yang tak dikehendaki, dan (3) menghilangkan koto ran ikan dan menguraikan produk atau zat yang beracun menjadi tak beracun untuk ikan.
\end{abstract}

KATA KUNCl: akuarium, filter, jenis-jenis ikan hias, jenis-jenis filter

\section{PENDAHULUAN}

Perkembangan ikan hias di Indonesia mengalami kemajuan yang terus meningkat, terutama ikan hias air tawar asli Indonesia. Dari sekian banyak jenis ikan hias, tidak semuanya telah dapat dibudidayakan. Dalam membudidayakan ikan hias harus diperhatikan bahwa masing-masing jenis mempunyai sifat dan kebiasaan hidup yang berbeda-beda, misalnya dalam cara pemijahan, bertelur ataupun menyusun sarangnya. Bila kita berniat untuk memelihara ikan pada akuarium atau wadah pemeliharaan, maka salah satu yang perlu diperhatikan adalah pemilihan jenis ikan yang akan dipelihara. Ikan hias yang dipelihara harus bisa memberikan kepuasan terhadap orang yang melihatnya, jika kita punya kolam atau bak yang posisinya di bawah, bila ditanam ikan lohan atau oskar maka ikan tersebut tidak akan terlihat indahnya. Lohan atau oskar mempunyai keindahan warna pada sisi samping badannya jadi jika dipelihara di kolam sisi samping badannya tidak akan kelihatan oleh kita.

Mengamati kegiatan usaha perikanan khususnya ikan hias tentunya tak dapat dipisahkan dengan sarana penunjang yang yang tak kalah pentingnya dengan usaha ikan hias itu sendiri yaitu "AKUARIUM" karena betapapun indahnya ikan hias apabila tidak ditunjang dengan penampilan akuarium serta dekorasi yang memadai, maka sesungguhnya nilai keindahan itu telah berkurang dan ini hanya bisa dicapai melalui penanganan yang tekun dan berkelanjutan. Apabila anda mulai memiliki hobi baru yaitu memelihara ikan hias dalam akuarium, maka jangan kaget bahwa akan banyak dijumpai hal-hal yang membutuhkan banyak pertimbangan dan keputusan yang harus dibuat. Mungkin akan menghadapi banyak pertanyaan, seperti seberapa besar akuarium yang akan digunakan? di mana akan ditempatkan? ikan apa saja yang akan dipelihara? filter apa yang akan digunakan agar ikan dapat hidup terus? dan lain sebagainya. Menggunakan filter memang banyak pilihan, dengan banyak desain untuk setiap tipe. Walaupun demikian dari semuanya itu dasar dalam penggunaan filter hanya tiga hal yaitu: (1) menghilangkan atau mengangkat kotoran atau sisa kotoran dari air, seperti pakan yang tak termakan, atau material yang ada di air. Ini disebut filter mekanis, (2) mengangkat atau menghilangkan bahan kimia dari air yang membuat air menjadi berwarna (warna coklat)/keruh atau bahan yang tak dikehendaki. Secara logika disebut filter kimia, dan (3) menghilangkan (sebenarnya merubah) kotoran ikan dan menguraikan produk atau zat yang beracun menjadi tak beracun untuk ikan. Ini yang disebut sebagai filter biologi.

Dalam artikel ini, akan dibahas beberapa jenis filter yang dapat digunakan untuk mendukung pemeliharaan ikan hias dalam wadah akuarium. Walaupun yang 
diketengahkan adalah merupakan dasar dari penggunaan filter yang mungkin telah diketahui, tetapi tak ada salahnya tulisan ini dimuat untuk menambah pengetahuan agar lebih lengkap.

\section{Jenis-Jenis Filter untuk Akuarium}

\section{Filter Mekanis/Fisik}

Sesuai dengan namanya, filter ini bekerjanya secara mekanis sehingga fungsinya hanya menyaring kotoran, sisa pakan, debu, dan koloid yang berada di dalam air budidaya. Material filter mekanis adalah spons, ijuk, atau serat kapas. Filter mekanis pada umumnya dapat dikonstruksikan, baik sebagai filter internal maupun filter eksternal. Dalam penggunaannya, filter ini perlu dicuci setiap periode waktu tertentu, misalnya dua hari atau seminggu sekali. Filter mekanis dapat digunakan sebagai prafilter, yaitu filter awal sebelum air masuk ke proses filter biologi atau kimia. Hal ini disebabkan partikel besar seperti debu dan koloid tidak dapat atau sulit terproses, baik secara kimia maupun biologi. Terdapat filter mekanis jenis tertentu apabila sudah lama pemakainnya akan dapat berfungsi sebagai filter biologi.

\section{Filter Kimia}

Bentuk filter jenis ini berupa absorben atau bahan kimia penyerap maupun pengikat sisa metabolit beracun yang ada dalam air. Filter kimia digunakan pada kondisi tertentu dengan reaksi cepat atau memineralisasi substansi organik dengan cepat. Berbeda dengan filter biologi yang dapat bertahan lama, daya kerja dan batas aktif filter ini sangat tergantung pada material yang digunakan dan kapasitas daya serapnya. Ada beberapa bahan yang berfungsi sebagai filter kimia, di antaranya ialah arang aktif, ozon, dan sinar ultraviolet, resin, zeolit, serta peat, penjelasannya sebagai berikut:

1. Arang aktif atau karbon aktif merupakan bahan berspektrum absorbsi yang luas. Dalam bentuk butiran (granula) atau tepung (powder) merupakan tipe dari filter fisika kimia (mekanis dan kimia). Karbon aktif meniadakan warna (discoloration), fosfat, klorin, kloramin, logam berat, dan berbagai bahan beracun dengan berbagai tingkatan. Bahan ini memang sangat ideal untuk prafilter, terutama menyingkirkan racun pada air minum (PAM). Namun, karbon aktif tidak dapat menyerap atau menyingkirkan amoniak, nitrit atau nitrat. Oleh karena itu, karbon aktif tidak cocok digunakan sebagai filter biologi. Daya aktif (life span) karbon umumnya hanya beberapa jam atau beberapa hari saja sehingga perlu sering diganti. Itulah sebabnya penggunaan karbon ini sebagai media filter untuk jangka lama tidak tepat. Bahan arang aktif ini pun kurang cocok untuk air tawar karena daya serap mineralnya sangat tinggi sehingga mineral dalam air cepat habis. Dibanding dengan air tawar, pada penggunaan di air laut arang aktif ini akan lebih bermanfaat dan efektif.

2. Ozon $\left(\mathbf{O}_{3}\right)$ dan sinar ultraviolet biasanya digunakan sebagai desinfektan untuk memberantas mikroorganisme patogen pada ikan seperti virus, bakteri, jamur, dan protozoa. Penggunaan ozon pun dapat memecah substansi amoniak yang sifatnya beracun menjadi substansi tidak beracun (nitrat). Ozon dibuat dengan menggunakan ozonator yang dialiri udara beroksigen. Alat ini mengubah oksigen menjadi ozon dan dialirkan ke dalam air pemeliharaan ikan. Sementara sinar ultraviolet dibuat dengan menggunakan lampu neon berwarna ungu (violet). Lampu neon ini dipasang di atas akuarium. Sinar ungu yang masuk ke air berfungsi sebagai desinfektan. Dengan menggunakan ozon atau sinar ultraviolet, ikan akan tercegah dari serangan penyakit. Sumber penyakit yang terkena ozon atau sinar ultraviolet akan mati. Sistem ini memang jarang digunakan, biasanya hanya untuk akuarium pajangan, terutama untuk ikan hias laut. Saat ini mulai ada peternak diskus yang menggunakannya. Penyebab ozon jarang digunakan adalah karena harganya mahal, penerapannya pun harus hatihati. Kadar ozon harus pas. Kalau terlalu besar, insang ikan akan rusak. Sebaliknya kalau terlalu sedikit, penggunaannya tidak efektif. Selain itu, kalau terkena paparan ozon orang bisa sakit kepala dan mual. Sedangkan, penggunaan ultraviolet (UV) hanya efektif pada air jernih. Bila digunakan pada air keruh, daya desinfektannya hanya dapat menembus beberapa sentimeter saja dari permukaan air. Sinar ini pun memiliki pengaruh pada manusia. Kalau sinar ultraviolet terkena kulit manusia, dapat menyebabkan kanker kulit dan bila terpapar ke mata, jaringan mata dapat mengalami kerusakan. Oleh karena itu, akuarium yang dipasangi lampu UV biasanya ditutup rapat.

3. Resin dapat dibandingkan dengan magnet yang bekerja sebagai penarik substansi terlarut seperti koloid dan substansi spesifik seperti amoniak dan nitrat. Sebagai media filter, resin akan menarik seluruh nitrat. Ada berbagai tipe resin yang dapat mengikat berbagai jenis substansi. Penggunaannya memang cukup banyak. Hanya saja, kapasitas resin sangat terbatas. Bila sudah jenuh, resin dapat dicuci dengan air garam. Untuk itu, sangat dituntut kerajinan mencucinya. 
4. Zeolit sangat baik digunakan sebagai absorben amoniak dengan aliran air cukup. Namun, zeolit ini tidak efektif untuk penggunaan di air laut. Ada dua macam zeolit yang dapat digunakan, yaitu zeolit alam dan sintetis. Zeolit sintetis banyak diperjualbelikan dalam bentuk bola-bola disebut zeoball. Seperti halnya resin, penggunaan zeolit pun akan mencapai tingkat kejenuhan, sehingga perlu ada pengontrolan dan penjadwalan pencucian agar daya kerjanya tetap baik. Akan lebih baik lagi penggantian secara teratur agar kesehatan ikan tetap terjamin.

5. Peat merupakan bahan filter buatan Kanada dan Jerman Utara. Bahan ini sangat membantu banyak akuaris di dunia karena substansinya sangat bagus dan memberikan pengaruh positif terhadap air pemeliharaan ikan. Bahan peat mengandung tanin, fulvin, dan asam humus (humic acid) sehingga bekerja mereduksi atau menurunkan $\mathrm{pH}$ dengan cara menukar ion secara alami, mengurangi kandungan karbonat, serta mengikat logam berat dan bahan racun dalam air. Senyawa aktif peat juga terdapat dalam air habitat asli diskus. Oleh karena itu, bahan ini sangat baik digunakan dalam pemeliharaan diskus. Dengan peat air akan berubah menjadi berwarna, tetapi akan sangat baik bagi ikan karena warna badannya akan menjadi cemerlang. Selain itu, juga dapat merangsang ikan yang sudah lama tidak memijah menjadi mau memijah.

\section{Filter Biologi}

Berfungsi sebagai pengurai senyawa nitrogen yang beracun menjadi senyawa tidak beracun melalui proses nitrifikasi dan nitratasi. Proses ini dilakukan oleh bakteri perombak. Material filter dapat berupa kerikil kecil, pasir kasar, serat gelas, atau spons.

Nitrifikasi merupakan proses oksidasi amoniak (beracun) menjadi nitrit (kurang beracun) oleh bakteri nitrosomonas. Sementara nitratasi merupakan proses lanjutan oksidasi nitrit menjadi nitrat oleh bakteri nitrobakter. Pada keadaan khusus, dapat terjadi reaksi atau proses denitrifikasi oleh bakteri Pseudomonas denifrificans. Denitrifikasi adalah proses terurainya nitrat $\left(\mathrm{NO}_{3}\right)$ menjadi gas nitrogen $\left(\mathrm{N}_{2}\right)$ dan gas oksigen $\left(\mathrm{O}_{2}\right)$ yang keduanya dapat menguap. Proses ini pun tentunya akan berpengaruh pada naik turunnya $\mathrm{pH}$. Saat berlangsung proses nitrifikasi akan terjadi penurunan $\mathrm{pH}$, sedangkan saat berlangsung proses denitrifikasi akan terjadi kenaikan $\mathrm{pH}$. Secara fisik, semua filter biologi harus berupa bahan yang dapat memperluas permukaan atau membuat area permukaan menjadi besar seperti poripori sehingga koloni bakteri perombak (nitrosomonas dan nitrobakter) dapat tumbuh dan berkembang. Bakteri perombak terdapat atau ada di sembarang tempat dan akan tumbuh baik kalau tempat dan lingkungannya memenuhi syarat. Di akuarium atau bak, bakteri tersebut akan tumbuh di dinding atau di sudut-sudut wadah. Agar dapat hidup, bakteri membutuhkan aliran nutrien yang konstan sebagai pakan dan suplai oksigen yang cukup. Oleh karena itu, bakteri ini akan hidup sangat baik pada air mengalir dengan kondisi aerob karena terdapat banyak oksigen.

Struktur filter yang berpori banyak akan menambah luasan permukaan sehingga menyebabkan bakteri perombak dapat hidup dan berkoloni. Akibatnya jumlah bakteri akan menjadi lebih banyak. Dengan demikian, substansi organik hasil metabolisme ikan akan lebih banyak terurai dan kualitas air pun akan lebih cepat diperbaiki. Dengan melihat proses yang telah dijelaskan, maka sebenarnya filter biologi merupakan sesuatu yang hidup sehingga memerlukan oksigen, pakan, dan tempat tinggal, serta dapat mengeluarkan buangan metabolit. Disebut hidup karena diperlukan organisme hidup berupa bakteri perombak. Pakannya berupa amoniak dan nitrit sebagai hasil buangan beracun, sedangkan buangan dari bakteri berupa nitrat adalah tidak beracun. Sementara tempat tinggalnya berupa permukaan yang cukup luas seperti pori-pori. Adanya syarat hidup tersebut yang apabila dikondisikan optimal maka bakteri akan tumbuh dengan baik sehingga filter pun akan berfungsi dengan baik pula.

Filter biologi sebaiknya dibuat dengan aliran atau arus yang sedikit lambat, sehingga akan memberikan kesempatan bagi bakteri untuk lebih banyak bekerja optimal yaitu merombak metabolit sehingga fungsi filter akan lebih baik. Pertumbuhan bakteri sangat dipengaruhi oleh suhu dan $\mathrm{pH}$. Nilai optimalnya berada pada $\mathrm{pH} 7,0-7,5$ dan suhu $28^{\circ} \mathrm{C}-30^{\circ} \mathrm{C}$. Pada kondisi di luar nilai pH dan suhu tersebut maka bakteri tidak dapat bekerja optimal sehingga efektivitas dari filter pun menurun. Kebanyakan ikan hias air tawar suhu optimalnya berada di bawah suhu tersebut yaitu antara $22^{\circ} \mathrm{C}-27^{\circ} \mathrm{C}$ maka tentunya tenaga filter juga akan lebih lambat bekerja. Oleh karena itu, penggunaan filter kimia atau absorben seperti resin, zeolit maupun karbon aktif bisa lebih baik walaupun harus lebih sering dilakukan penggantian air. Efektivitas filter biologi juga tergantung pada waktu untuk tumbuh dan bekerjanya bakteri secara optimal, yaitu sekitar 15 hari sampai enam minggu sejak dibuat. Sebagai tanda kalau bakteri sudah tumbuh ialah air akan menjadi jernih dan baunya segar. Filter ini umumnya akan stabil dalam waktu enam bulan, tergantung 
keseimbangan ukuran filter dan jumlah ikan di dalamnya. Apabila ingin bakteri tumbuh dengan cepat maka inokulasi bakteri pun dapat dilakukan, yaitu dengan mengalirkan atau memberi air lama atau air dari wadah pemeliharaan ikan yang lain yang sudah ada bakterinya. Pada kondisi yang terlalu banyak amoniak dan nitrit akibat terlalu padatnya ikan atau filter yang terlalu kecil maka filter akan cepat jenuh sehingga bakteri tidak mampu bekerja maksimal. Dengan demikian, filter tidak efektif lagi dan air tetap saja tidak aman untuk ikan, penggantian air amat diperlukan.

Walaupun tidak ada aturan baku tentang hubungan jumlah ikan dengan kapasitas filter, namun akan lebih baik kalau dibuat tahapan tentang jumlah ikan yang dipelihara. Sebagai contoh, filter yang baru dibuat diisi dahulu dengan ikan yang toleran atau kuat dengan goncangan kualitas air agar bakteri tumbuh dengan baik. Kepadatan ikan saat awal ini sebaiknya rendah. Pada awalnya air akan tampak keruh, tetapi lama-kelamaan akan menjadi jernih. Hal ini menandakan bahwa filter sudah aktif dan bekerja dengan baik. Setelah itu, barulah kepadatan ikan disesuaikan atau ditambah. Filter biologi sebaiknya dirawat agar tahan lama dan bakterinya tetap hidup, dengan menjaga aliran air. Kalau aliran air terputus dalam waktu yang lama maka biasanya bakteri akan mati sehingga tentunya filter harus dibongkar dan dibersihkan agar tidak bau.

Yang harus diingat lama-kelamaan konsentrasi mineral maupun garam di dalam air pemeliharaan yang dibutuhkan ikan untuk keseimbangan pengaturan osmose atau osmoregulasi akan berkurang ataupun habis. Hal ini karena ikan air tawar menarik mineral atau garam untuk kebutuhan hidupnya dari air media di mana dia hidup. Selain itu, kadar nitrat yang diproduksi terus-menerus juga akan semakin tinggi. Walaupun nitrat tidak beracun, namun pada kadar yang tinggi dan terjadi kekurangan oksigen maka nitrat akan dapat tereduksi menjadi sulfida yang sangat beracun bagi ikan. Senyawa sulfida ini memang sulit dikeluarkan atau disingkirkan dari sistem filter. Untuk itulah, perlu adanya penggantian sebagian air dalam jangka waktu tertentu, sebaiknya 2-3 bulan sekali, agar mineral atau garam juga tercukupi. Penggantian air ini pun dapat mengeluarkan atau menurunkan kadar nitrat maupun sulfida.

\section{Filter yang Banyak Tersedia di Pasaran}

Sponge filter (Filter biologi paling sederhana atau primitif)

Bakteri pengurai berada atau menempati sponge, dan harus secara periodik dapat dicuci atau dibersihkan dari detritus atau kotoran yang dapat membuat aliran airnya macet. Sponge filter dapat digunakan pada hampir semua sistem yang membutuhkan filtrasi biologi, tapi amat cocok untuk wadah yang tanpa substrat (biasanya para peternak) di mana telur atau burayak kecil dapat tersedot bila menggunakan filter yang lain. Filter ini berbentuk batang bulat atau persegi yang dilekatkan ke pipa-pipa plastik yang di dalamnya diberi selang aerasi. Aliran air bergerak akibat adanya dorongan udara dari air. Filter ini lebih sering digunakan dalam pemeliharaan larva.

\section{Box Filter (Sering disebut Corner filter)}

Merupakan yang banyak dipilih dalam kebanyakan akuarium hanya saja filter ini kapasitasnya terbatas untuk menghilangkan material-material (karena arus yang lambat) dan tak punya kapasitas filtrasi kimia. Filter ini banyak dijual dengan tambahan isi karbon aktif (untuk filter kimia) dan fiber polyester untuk filter mekanis. Walaupun tidak dapat memenuhi semua kebutuhan filtrasi, tetapi bila diisi dengan fiber polyester akan menjadi filter biologi yang baik. Banyak peternak yang menggunakannya untuk memelihara anak ikan, karena aliran air yang lembut dan aman untuk larva (tidak tersedot ke filter). Sesuai dengan namanya adalah box atau kotak biasanya terbuat dari plastik dan ditaruh di sudut akuarium. Aliran airnya digerakkan dari pompa udara atau blower dan di dalamnya adalah berbagai material filter seperti karbon, spons, atau kapas.

Under Gravel Filter (UGF) merupakan filter yang tertua, dan simpel)

Berupa plate atau lembaran plastik yang berlubanglubang, di desain untuk ditempatkan di bawah gravel atau kerikil atau pasir kasar. Aliran air bisa dibuat dengan motor atau dorongan udara dari airasi. Selain itu, juga murah, efektif dan bahannya mudah didapatkan. Namun demikian untuk telur dan larva tak cocok karena dapat "terjebak" masuk ke gravel dan dapat mati. Demikian pula ikan-ikan yang suka mengais atau menggali-gali seperti beberapa ikan catfish, jenis-jenis siklid, mas koki dan sebagainya. UGF juga tak begitu cocok bila untuk tanaman air, karena akan susah untuk menanam pada dasar yang tak ada tanah liatnya. Tanaman air biasanya membutuhkan sedikit tanah liat, tanah, dan sebagainya yang dapat menyumbat filter. Mungkin juga bisa tetapi sebaiknya menanamnya dalam pot kecil, dan ditanam dalam gravel agak dalam. Pilihan selanjutnya adalah pada motor dari UGF head pump atau dengan dorongan dari dalam batu aerasi saja. Pompa aliran airnya lebih kuat daripada aerasi yang lebih lembut, walaupun pompa pemeliharaannya lebih mudah (secara periodik dapat diganti) misal membran pompanya. Namun demikian amat 
susah untuk mebuat gerakan air pada pompa seperti pada aerasi. Jika pilih powerhead, maka dapat dibuat opsi dengan cara menggunakan konfigurasi aliran reverse/ bolak-balik. Artinya sementara air ditarik ke atas melalui pipa uplift, powerhead juga mendorongnya ke bawah. Air akan mengalir melewati gravel dari naik ke atas, daripada turun ke bawah (aliran konvensional). Keuntungan dari ini adalah gravel akan selalu bersih, karena pakan dan segala kotoran yang secara alami turun ke dasar akuarium/ wadah akan langsung terbawa masuk ke gravel. Bagian bawah ini akan menjadi terlihat berapa banyak detritus yang ada, dan akan terkumpul di atas substrat dengan jelas, sehingga mudah diambil atau dibersihkan. Sehingga bila sudah sejak awal direncanakan untuk menggunakan sistem UGF maka adanya kotoran sebaiknya diminimalisir. Karena bila tidak maka akan banyak kotoran di gravel sehingga akan diperlukan untuk membersihkan gravel yang tentunya akan membongkar seluruh sistem. Yang menjadi masalah lagi apabila gravel menjadi mampet, tetapi juga kompetisi oksigen antara ikan dan bakteri di dalam filter yang berada di dasar akan menjadi miskin oksigen.

\section{Wet/dry (W/D) filter atau sering dikenal dengan nama Trickle filter}

Filter ini, berupa wadah atau akuarium yang terletak di dasar atau lantai (bisa berupa unit yang menggantung di belakang akuarium atau wadah pemeliharaan yang berupa kabinet). Dimotori oleh pompa eksternal dan khusus berisi beberapa tipe media biologi seperti bioball atau material fiber. Karena sifatnya yang "terbuka" sehingga memungkinkan oksigen masuk lebih banyak. Filter ini sangat berguna untuk sistem yang besar (misal lebih dari 200 liter) yang dapat dipadukan dengan modular filter atau canister, di mana UGF tak bisa digunakan seperti pada akuarium tanaman air. Keuntungannya adalah dalam dry filter dapat ditambahkan media kimia untuk dua harapan/kepentingan. Yang pertama hanya membersihkan seperti pada simple prefilter. Yang kedua adalah dapat dibuat sistem overflow atau aliran dan sistem sipon, dan membutuhkan pompa eksternal yang biasanya cukup besar. Untuk yang kecil maka unit dengan isi yang dibuat sendiri lebih praktis. Filter yang dibuat bersama dengan UGF adalah “Outside Power Filter' (OPF). OPF ini tidak mahal dan dapat dipakai sebagai filtrasi kimia dan mekanis dalam waktu yang bersamaan. Dalam beberapa hal dapat pula diisi media biologi aktif seperti busa yang disisipkan dalam roda (Wheel). OPF (Outside Power Filter) mempunyai tiga dasar tipe. Satu yang populer menggunakan cartridge atau wadah yang berisi polyester fluff "jacket" yang berisi karbon aktif. Wadah ini amat awet sehingga banyak orang menggunakannya. Isinya dapat diganti setiap bulan. Yang kedua adalah OPF menggunakan media "stacked/ bertumpuk". Letakkan dalam wadah filter floss, karbon (atau yang lain), sponge atau apa saja yang ingin digunakan. Keuntungannya adalah dapat dirubah-rubah, hanya karbon aktif bila digunakan untuk obat-obatan kurang cocok. Apapun yang digunakan yang hsrus dipikirkan adalah ukuran dari filter. Yang penting adalah filter harus dapat mengganti atau mengalirkan air sekitar 3-4 kali setiap jam. Misalkan anda mempunyai bak ikan 100 liter maka harus kuat membuat derajat filter ini sekitar 500 liter. Bila anda mempunyai uang yang tak banyak maka cobalah dengan filter canister. Seperti Outside Power Filter ada dua type yang bagus yaitu cartridge dan media tumpuk. Canisterb filter adalah filter yangdigunakan pada wadah yang bervolume lebih dari 30 galon atau liter. Mereka sangat menguntungkan atau bagus karena proporsional dalam memfilter lebih dari media di OPF dengan derajat aliran dan dapat disembunyikan dalam almari atau kabinet akuarium. Pompanya dapat pula digunakan untuk mendorong W/D, roda eksternal biologi kontak, air terjun atau air mancur. Harganya lebih murah dari OPF, dan mempunyai banyak pilihan ukuran. Penggunaan karbon aktif dapat dilakukan, walaupun banyak yang mengatakan karbon ini membuat ikan akan sakit. Dapat pula beberapa merk melepaskan banyak fosfat tetapi ini hanya pada akuarium laut, bukan pada air tawar. Karbon aktif ini akan dapat menyerap mikroorganisme, gas-gas beracun, dan bahan-bahan berbahaya lainnya.

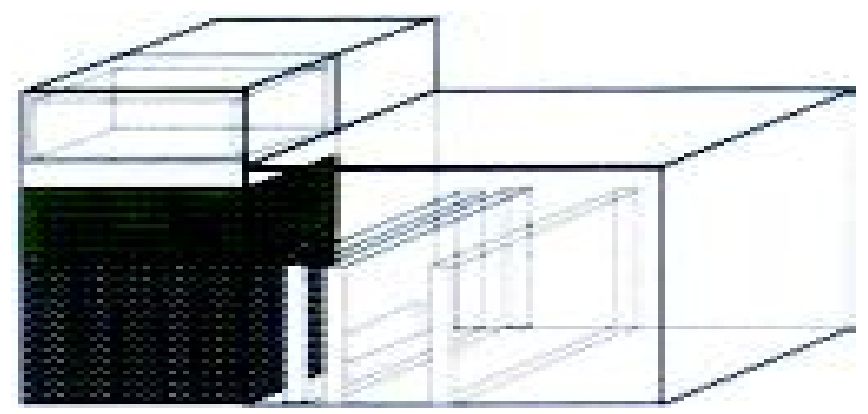

Trickle filter (Wet and dry filter)

\section{Modular Filter}

Banyak digunakan pada akuarium yang cukup besar, di atas 400 liter. Merupakan filter yang dapat dibeli atau dibuat sendiri. Terdiri atas pompa air dan modul single seperti canister karbon, unit cartride yang berlipat-lipat, atau unit filter biologi. Dapat pula lebih komplek seperti ditambah lagi heater, sinar UV dan lain-lain. Modular filter terbuat dari banyak komponen yang dapat dibongkar pasang, biasanya dimotori pompa eksternal. Berupa 
kontainer terpisah yang berisi media filter biologi, mekanik dan kimia dan sering juga ada tempat heater khusus, dan lain-lain.

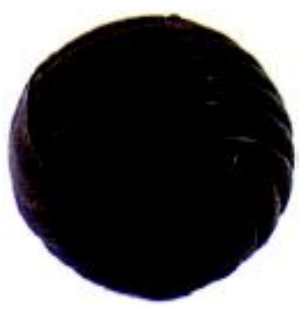

Black bioball

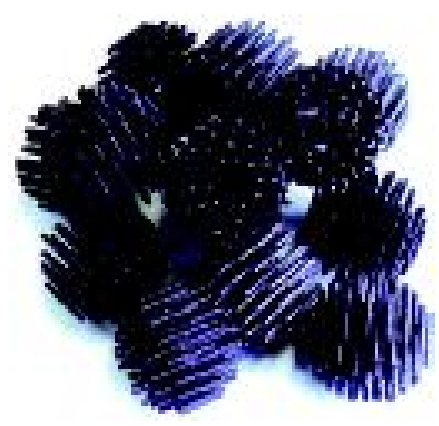

Bioball generasi sebelumnya, disebut juga bioball rambutan

\section{Teknik Meletakkan Filter dalam Akuarium}

Arus air dalam filter sebaiknya tidak terlalu cepat. Arus yang lambat akan lebih efektif untuk memberikan kesempatan bagi filter bekerja dengan baik. Apalagi ada beberapa jenis ikan seperti diskus yang tidak cocok dengan arus air yang cepat, dan hanya cocok pada air tenang. Menurut penelitian umumnya perputaran air yang baik dan efisien pada filter akuarium air tawar sekitar 1-2 jam untuk mengganti seluruh air dalam akuarium. Untuk itu, teknik meletakkan filter dalam akuarium juga harus tepat sehingga tidak mengganggu dan merusak pemandangan ikan yang ada dalam akuarium. Teknik meletakkan filter dalam akuarium terbagai atas:

\section{Filter Internal}

Wadah pemeliharaan yang dapat menggunakan filter ini dapat berupa bak ataupun akuarium. Oleh karena letaknya di dalam wadah, ukuran filter tentu harus kecil. Ada dua macam filter internal, yaitu filter yang diletakkan di pojok wadah (corner filter), filter yang diletakkan di bawah atau dasar wadah (bottom filter). Filter pojok umumnya bekerja sebagai filter mekanis, yaitu mengangkat koloid atau material terapung dalam air sehingga harus sering dibersihkan. Itulah sebabnya material filter biasanya hanya satu macam, yaitu spon atau busa. Penggunaan busa sangat baik karena kalau akan dicuci sangat mudah dilepaskan dan dipasangkan kembali. Filter dasar (bottom filter) juga disebut undergravel filter/UGF. Filter ini sudah lama dikenal dan digunakan hobiis, terutama untuk akuarium pajangan. Lapisan paling bawah umumnya berupa saringan dari plastik atau kawat kasa halus. Saringan ini menyebabkan adanya ruangan antara kasa dan dasar akuarium untuk air bersih. Material filter seperti kerikil atau pasir kasar yang tidak lolos pada saringan ditempatkan di saringan. Sirkulasi air dari bawah atau dasar ke atas wadah dapat dilakukan dengan air water lilt atau pompa udara melalui pipa atau dengan power head pump yang ditempatkan di pojok wadah. Filter dasar dapat berfungsi sebagai filter mekanis, filter biologi, maupun substrat untuk ikan. Hanya saja untuk membersihkan filter ini agak sulit karena harus mengangkat atau memindahkan semua ikan terlebih dulu.

\section{Filter Eksternal}

Peletakannya dapat sejajar atau di sisi, di atas, atau di bawah wadah pemeliharaan ikan. Ukurannya dibuat sesuai selera, tempat, jumlah ikan, dan ukuran wadah sehingga dapat lebih kecil, sama, atau lebih besar dari ukuran wadah. Filter eksternal sangat baik, dalam fungsinya sebagai filter biologi, filter demikian dapat memperluas permukaan dengan penggunaan berbagai macam material. Pembersihannya pun akan lebih mudah karena tidak perlu mengganggu ikan dalam wadah pemeliharaan. Material filter dapat dibuat beberapa lapisan dari berbagai bahan seperti busa, ijuk, pasir kasar, dan zeolit. Umumnya, material filter terdiri atas 2-3 lapisan. Penyusunannya dapat vertikal dari bawah ke atas ataupun horisontal dengan aliran air horisontal. Dengan adanya beberapa lapisan menyebabkan filter dapat berfungsi sebagai filter mekanis, filter kimia (pada permulaan penggunaan), dan filter biologi (setelah agak lama digunakan). Sebagai contoh adalah lapisan filter dari atas ke bawah berupa serabut kapas atau spon, kerikil, zeolit, dan ijuk. Bisa juga susunan lapisannya hanya spon dan kerikil saja ataupun susunan lainnya. Spon atau serabut kapas berfungsi sebagai filter mekanis yang menyaring material besar seperti kotoran ikan, sisa pakan, atau ikan mati, sehingga diletakkan di bagian atas lapisan karena harus mudah diangkat dan dibersihkan. Pembersihan lapisan atas ini untuk menjaga agar aliran air menjadi lancar. Kerikil dan ijuk akan menjadi filter biologi yang baik dan bekerja aktif dalam waktu dua minggu setelah sistem filter berjalan. Sementara zeolit digunakan untuk menyerap amoniak atau hasil metabolit aktif segera setelah sistem filter berjalan sehingga fungsinya menjadi filter kimia.

\section{Susunan Model Filter pada Akuarium}

Ada dua macam susunan model filter, yaitu model tunggal dan seri. Filter model tunggal merupakan satu filter yang hanya digunakan untuk satu wadah pemeliharaan ikan. Sementara filter model seri merupakan satu atau dua filter untuk dua atau lebih wadah pemeliharaan yang diatur atau disusun dalam rangkaian paralel ke samping atau ke atas. Filter model seri akan 


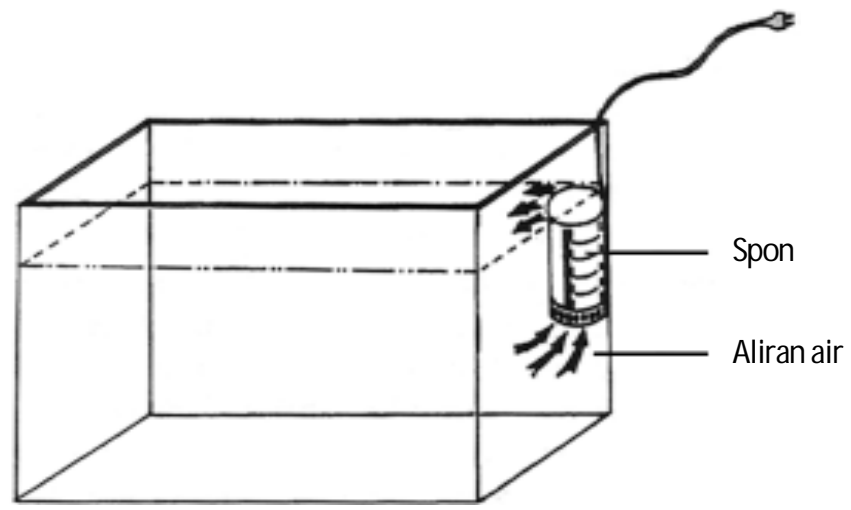

Filter internal pojok

Gambar 1. Filter tunggal hanya untuk satu tempat pemeliharaan

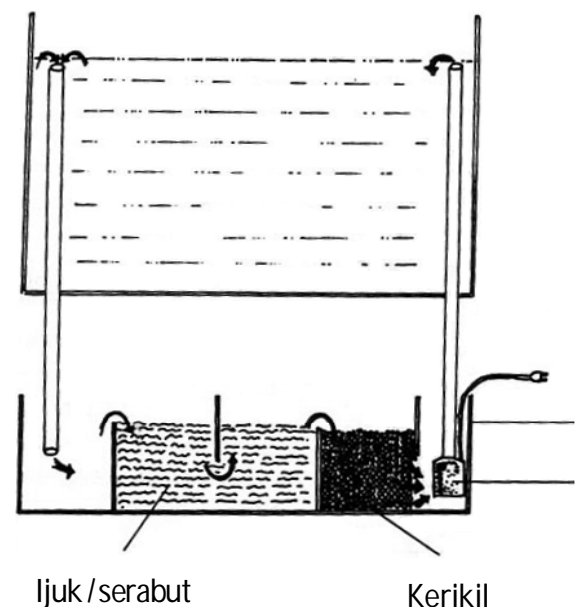

Filter bawah horisontal

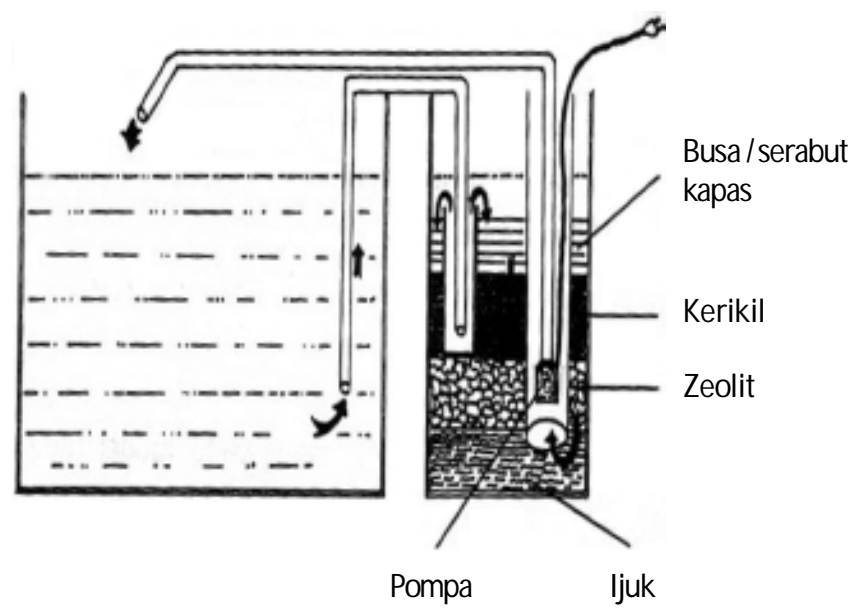

Filter samping vertikal

Gambar 2. Filter seri satu filter untuk banyak akuarium

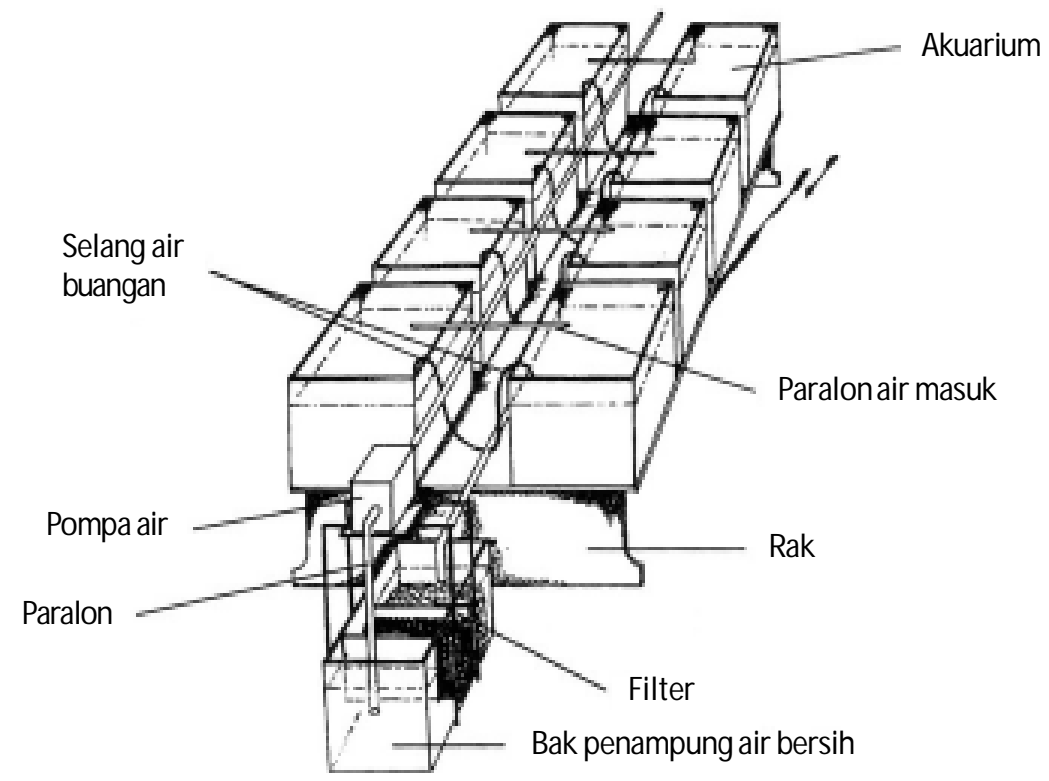

Gambar 3. Jenis filter seri yang lain, digunakan untuk lebih dari satu akuarium 
baik dan efisien untuk wadah pemeliharaan ikan dengan volume kecil. Selain itu, model seri dapat menghemat tempat karena dapat disusun dalam rangkaian ke atas.

Kekurangan dari model seri antara lain perancangannya memerlukan keahlian dan keterampilan, terutama dalam membuat keseimbangan aliran air pada tiap wadah. Selain itu, kalau salah satu wadah bermasalah (misalnya terkena penyakit) maka penularannya ke wadah lain akan cepat. Demikian pula kalau aliran air pada salah satu bak tersumbat maka wadah lain akan terpengaruh.

\section{PENUTUP}

Dalam membudidayakan ikan hias harus diperhatikan bahwa masing-masing jenis ikan mempunyai sifat dan kebiasaan hidup yang berbeda-beda. Bila kita berniat untuk memelihara ikan pada akuarium atau wadah pemeliharaan, maka salah satu yang perlu diperhatikan adalah pemilihan jenis ikan yang akan dipelihara dan aksesoris yang digunakan serta dekorasi akuarium yang dibuat.

Salah satu hal penting yang perlu diperhatikan adalah penggunaan filter yang merupakan alat bantu untuk sintasan ikan selama dipelihara dalam akuarium. Banyak jenis filter yang digunakan, meskipun demikian dari semuanya itu dasar dalam penggunaan filter hanya tiga hal yaitu: (1) menghilangkan atau mengangkat kotoran atau sisa kotoran dari air, seperti pakan yang tak termakan, atau material yang ada di air. Ini disebut filter mekanis, (2) mengangkat atau menghilangkan bahan kimia dari air yang membuat air menjadi berwarna (warna coklat)/keruh atau bahan yang tak dikehendaki. Secara logika disebut filter kimia, dan (3) menghilangkan (sebenarnya merubah) kotoran ikan dan menguraikan produk atau zat yang beracun menjadi tak beracun untuk ikan. Ini yang disebut sebagai filter biologi.

\section{DAFTAR ACUAN}

Ahmad, T., Sofiarsih, L., \& Kusmana. 2007. The growth of patin Pangasius hypopthalmus in close tank. Indonesian Aquaculture Journal, 2(1): 67-73.

Andrews, C., Exell, A., \& Carrington, N. 1988. The manual of fish health. Salamander Book. Tetra Press. Blacksburg, VA.

Axelrod, H.R., Burgess, W.E., Pronek, N., \& Wall's, J.G. 1995. Atlas of freshwater aquarium fishes. Eight edition. TFH Publication, Inc. New York-USA, 335 pp.

http://anton182.wordpress.com/2009/07/03/353/ diakses tanggal 30 Juli 2012.

Lesmana, D.S. 2002. Kualitas air untuk ikan hias air tawar. Cetakan ke-II. Penebar Swadaya. Jakarta, $88 \mathrm{hlm}$.

Sakurai, A., Sakamoto, Y., \& Mori, F. 1990. Aquarium fish of the world. Chronicle Book, San Fransisco, 288 $\mathrm{pp}$.

Suryanata, L. 2007. Aquarium Aquascaping. Aquarista. Jakarta, hlm. 135-216. 